\title{
Evaluation of Special Purpose Vehicle Organisation Skill Sets Taxonomy for Effective Public-Private Partnership Infrastructure Project Delivery
}

\author{
*Christy Gomez and Muhammad Gambo
}

Published online: 31 July 2016

To cite this article: Christy Gomez and Muhammad Gambo. (2016). Evaluation of special purpose vehicle organisation skill sets taxonomy for effective public-private partnership infrastructure project delivery. Journal of Construction in Developing Countries, 21 (1): 147-165. doi: 10.21315/jcdc2016.21.1.8

To link to this article: $h t t p: / / d x . d o i . o r g / 10.21315 / j c d c 2016.21 .1 .8$

\begin{abstract}
The necessary skill sets that public-private partnership (PPP) stakeholders bring together are recognised as being paramount to the success of any PPP project. From preliminary research findings it is clear that there is a strong bias towards business-oriented skills rather than service-oriented skills by the special purpose vehicle (SPV) organisation. This paper examines the skills sets required to ensure the effective delivery and implementation of the private sector-led PPP project with respect to the SPV organisation in order to deliver value for money (VfM). A comprehensive literature review was conducted to establish the various skills needed by the SPV organisation for the successful delivery of PPP infrastructure projects to form the basis of the research questionnaire. Questionnaire survey data obtained from a purposive sample of 48 public and private PPP stakeholders in Peninsular Malaysia was analysed using SPSS $v 18$ to establish the relative importance of the various skill sets. The findings indicate "legal and contracting knowledge" to be the most important and "conceptual skills" as the least important skill for the SPV organisation in PPP project implementation. The findings also indicated that there is a significant difference in the perception of public and private PPP stakeholders with respect to the importance of the "ability to clearly define technical and output specifications and standards for services to be procured", implying less importance given by the private sector with regard to this skill. Drawing on the understanding that skill sets are critical denominators of the organisational structure, this research is expected to influence the development of appropriate guidelines for skills prioritisation in the organisation of SPVs and the effective management of PPP concession projects.
\end{abstract}

Keywords: Special purpose vehicle, Public-private partnership, SPV skill sets, Infrastructure projects

\section{INTRODUCTION}

Public-private partnerships (PPP) is a collaborative approach for delivering infrastructure facilities primarily involving the public and private sectors working in co-operation and partnership with each other (Harris, 2003). It is essentially a partnership between public sector organisations and private sector investors primarily in the form of a standalone business venture referred to as the Special purpose vehicle (SPV). PPPs came into prominence as a result of the continued budgetary constraints faced by governments and the underlying need for operational efficiency, innovative technological and management skills, and 
more active involvement of private players in the delivery of public services (Chowdhury, Orr and Settel, 2009).

The concept of PPP has since progressed from the earlier approaches of just focusing mainly on private finance to take on a wider perspective of also bringing in key strengths available within the private sector requiring greater private sector involvement. Hence, PPP is seen as a system which is primarily aimed at achieving the best output possible by pulling together and mobilising funds, technologies, managerial skills, operational efficiencies and facilitating innovations that exists in the private sector (Akintoye, Edwards and Hardcastle, 2005; Huang et al., 2005).

Private sector involvement in infrastructure provision and services delivery is not an entirely new approach in Malaysia, but had been in existence since 1983, basically in the form of privatisation, whereby the public users pay for the services of the infrastructure projects rendered, projects such as toll roads, ports and independent power producers (IPPs), sewerage systems, etc. (Salleh and Siong, 2008). In 2006, after 22 years, the privatisation policy of the private sector's role in infrastructure delivery was metamorphosised into the PPP as the mechanism for improving the effectiveness of infrastructure delivery, from having initially focused on the Private Finance Initiative (PFI) mode of PPP. PPP was formally defined under the Ninth Malaysia Plan report (2006), as "the transfer to the private sector the responsibility to finance and manage a package of capital investment and services including the construction, management, maintenance, refurbishment and replacement of the public sector assets which creates a standalone business. The private sector will create the asset and deliver a service to the public sector client. In return, the private sector will receive payment commensurate with the levels, quality and timeliness of the service provision throughout the concession period" (Economic Planning Unit, 2006).

Under the Ninth Malaysian Plan (2006-2010), the government identified 425 projects worth RM 20 billion (USD 6 billion) to be procured through PPP (Abdul Rashid, 2007) and under the present 10th Malaysia Plan, 52 high impact projects worth RM 63 billion (USD 19 billion) have been identified for implementation under the PPP form of project delivery (Economic Planning Unit, 2006).

In year 2009, the Unit Kerjasama Awam Swasta (UKAS) or the Public-Private Cooperation Unit was formed for the regulation of PPP related activities in Malaysia. The structure of PPP procurement practiced in Malaysia has been identified to be similar to that found in the global PPP market, a typical SPV-based structure (Abdullah et al., 2012). Amongst the various PPP stakeholders, the SPV organisation is one of the key stakeholders, often referred to in loose terms as the private sector, which also includes investors and consultants who have specific roles. Booth and Skilling (2007) identified the role of key stakeholders in the PPP process as shown in Table 1.

It is noted that each role is critical and that specific stakeholders tend to have different interests that influences how they approach their role. The innovative form of project delivery in the form of PPP indeed requires a set of PPP specific skills to be possessed by the project stakeholders in order to enable the project to achieve its desired objectives in terms of efficiency and output. It is noted in the Royal Institution of Chartered Surveyors (RICS) report on project management of PFI projects that there are skills shortcomings in PFI projects, specifically with regard to management of the PFI projects and it is additionally noted that people with PFI experience are in short supply (RICS, 2003). It is 
undeniable that the innovative form of project delivery in the form of PPP requires a unique set of PPP-specific skills to be possessed by the project stakeholders in order to enable the project to achieve its desired objectives in terms of efficiency and output.

Table 1. Roles of Different Stakeholders in the PPP Process

\begin{tabular}{ll}
\hline Stakeholders & Roles \\
\hline Political decision makers & 1. Establish and prioritise goals and objectives of \\
& PPP and communicate these to the public \\
2. Approve decision criteria for selecting preferred & PPP option \\
3. Approve recommended PPP option \\
Staff & 4. Approve regulatory and legal frameworks \\
1. Identify company specific needs and goals of & PPP \\
Consumers & 2. Provide company specific data \\
3. Assist in marketing and due diligence process \\
4. Implement change \\
1. Communicate ability and willingness to pay for \\
service \\
2. Express priorities for quality and level of service \\
3. Identify existing strengths and weaknesses in \\
service \\
1. Provide feedback on the attractiveness of \\
various PPP options \\
2. Perform thorough and due diligence resulting in \\
competitive and realistic bidding
\end{tabular}

Source: Asian Development Bank (ADB) (2008)

Hence, the key motivation that led to the present study was to elucidate on the required skills that are required for the SPV organisation to deliver effective PPP infrastructure projects by which the preliminary research conducted by Gomez and Gambo (2013) showed a bias towards business related rather than to service related objectives by the SPV organisations.

The current lack of prioritisation on the required skills sets by the SPV organisation for current PPP project delivery in the Malaysian perspective can be attributed to the fact that over the short span of years since 2006, most infrastructure projects have been delivered via public sector organisations within the traditional design-bid-build procurement model, tending to rely on traditional skills. Whereas, PPPs are substantially different, featuring peculiar characteristics such as private sector led financing, risk allocation and long contract durations. 
Hence, without having a clear emphasis on PPP-specific skills (particularly SPV organisational skills), the current attempts at improving PPP delivery is viewed as being significantly constrained.

To summarise the work presented here, this paper is organised within the context of having identified a bias towards business related rather service related skills by the SPV organisations in Malaysia. The general background knowledge regarding PPP practice and the significant developments with regard to infrastructure delivery is described and related to as being strongly driven through the PPP agenda. The main body of the paper is structured according to the following sections:

1. literature review,

2. collection of research data,

3. survey data analysis and results and

4. implications, limitations and conclusion.

\section{LITERATURE REVIEW}

PPP offers several advantages as a means of procuring public infrastructure with regards to private sector participation (Walker, 1995), which includes:

1. The achievement and maintenance of a balanced risk return structure as a result of the private sector participation in the provision of such public infrastructure, thereby utilising the private sector capability of providing effective services.

2. As the private sector is known to possess better mobility than the public sector, it offers cost savings in projects in such aspects as planning, design, construction and eventually the operation. Furthermore, the private sector offers additional advantages of mitigating and relieving all the bureaucracies and administrative burden that is associated with public's provision of infrastructural facilities and services.

3. The private sector participation in providing infrastructures relieves the government of the huge financial burden that is associated with large scale infrastructure projects, as the government is known to be lacking in providing such huge resources that are required in the provision of such projects.

\section{Skills Sets for SPV Organisations in PPP Infrastructure Project Implementation}

The private sector-led SPV organisation is referred to as a limited liability project consortium which is created solely for the purpose of developing the PPP project. The SPV organisation in PPP project delivery is responsible for the equity financing, design, construction and subsequent operation and maintenance of the built facility (Gunawasa, 2012). PPP as a form of a collaborative venture between the public and private sectors is underpinned on the basis of leveraging on the expertise and operational capabilities of the private sector and also the support and regulatory capacities of the public sector in order to deliver the required PPP 
project in the most effective and value oriented way for the ultimate benefit of the overall stakeholders involved in the project (ADB, 2008).

To deliver a project, a wide variety of skills need to be acquired by the relevant stakeholders involved in the project. In order to enable the PPP project to achieve its desired objectives in terms of efficiency and output, a set of PPPspecific skills need to be possessed by the project stakeholders. Peterson and Van Fleet (2004) describe skills as the ability to either perform some specific behavioral task or the ability to perform some specific cognitive process that is functionally related to some particular task. Whilst according to Whetten (2005), skills are a vehicle through which strategy, practice, tools and techniques, personality attributes and style work are adopted to produce effective outcomes in organisations.

Successful PPP project delivery cannot be achieved unless the private sector-led SPV organisation are equipped with required skills and capabilities that will enable them to deliver the objectives that the particular PPP project seeks to achieve. There is the underlying need for the SPV organisation to possess the required capabilities in terms of delivering the PPP project in line with the output specifications as stipulated in the PPP contractual agreements. The scope of services in PPP project is defined in the output specification, which identifies a clear and articulated guideline as regards to the services to be delivered by the PPP project, and hence provides the framework which incorporates the needs of the public sector client and the responsibilities of the private sector operator, i.e. the SPV organisation (Robinson and Scott, 2009).

It is clear from various case studies that the lack of effective PPP skills by the SPV organisation led to the failure of several PPP projects. Examples of such PPP projects include the Philippines Navotas-I power project, which was initially rated to have favorable outcomes but subsequently became underutilised as a result of the lack of effective value for money (VfM) assessment capabilities of the SPV organisation. The emphasis had been on solely taking advantage of the capital raising and securing of private investment opportunities that the PPP procurement approach offers rather than seeking better outcomes as in the case of the traditional public procurement (Woodhouse, 2006; Chowdhury, Chen and Tiong, 2011). Whilst in Denmark, the waste water and cloak pipe net PPP project in the Farum Municipality failed due to the SPV's inappropriate financial capabilities, which resulted in fraud and mismanaged financial transactions (Koch and Buser, 2006).

With respect to the Malaysian practice of PPP, the lack of effective public stakeholder management by the SPV organisation and also the government resulted in the failure of the government's attempt to privatise the sewerage system covering Kuala Lumpur, Pulau Pinang, Labuan and Langkawi, where the Indah Water Consortium was reabsorbed after the government divested its holdings in the infrastructure facility. The opposition of the public users resulted in the failure of the private sector-led sewerage system and this is attributing to the fact that the public was unaware and not sufficiently educated about the PPP approach to infrastructure delivery, as well as being denied access to detailed information contained in the SPV consortium's proposals (El-Gohary, Osman and ElDiraby, 2006).

Hence, extensive literature review was conducted to identify the various SPV organisational skills required for the successful delivery of PPP projects. Through 
this extensive literature review, 12 skills were identified that were necessary for the SPV organisation in the delivery of PPP infrastructure projects. The skill sets are listed in Table 2 below.

Table 2. SPV Organisation Skills for PPP Infrastructure Project Implementation

\begin{tabular}{|c|c|c|c|c|c|c|c|c|c|c|}
\hline \multirow{2}{*}{ PPP Skills } & \multicolumn{10}{|c|}{ Source of Information } \\
\hline & A & B & C & D & $\mathbf{E}$ & $\mathbf{F}$ & G & $\mathbf{H}$ & J & K \\
\hline $\begin{array}{l}\text { Experience in negotiation and } \\
\text { arbitration }\end{array}$ & $\sqrt{ }$ & & & & & & & & & \\
\hline $\begin{array}{l}\text { Scoping in/out ability (ability to } \\
\text { forecast the future effects of } \\
\text { actions) }\end{array}$ & $\sqrt{ }$ & & & & & & & & & \\
\hline Conceptual skills & $\sqrt{ }$ & & & & & & & $\sqrt{ }$ & $\sqrt{ }$ & $\sqrt{ }$ \\
\hline Project management skills & $\sqrt{ }$ & & & & & & $\sqrt{ }$ & & & \\
\hline Communication capabilities & $\sqrt{ }$ & & & & & & & & & \\
\hline Coordination skills & $\sqrt{ }$ & & & & & & & & & \\
\hline Value for money assessment ability & & $\sqrt{ }$ & & & & & & & & \\
\hline $\begin{array}{l}\text { Ability to formulate appropriate } \\
\text { performance measures and } \\
\text { development of monitoring } \\
\text { systems to determine performance }\end{array}$ & & $\sqrt{ }$ & & & & & & & & \\
\hline $\begin{array}{l}\text { Ability to clearly define technical } \\
\text { and output/outcome } \\
\text { specifications and standards for } \\
\text { services to be procured }\end{array}$ & & $\sqrt{ }$ & & & & & & & & \\
\hline $\begin{array}{l}\text { Technical and operational } \\
\text { innovation skills }\end{array}$ & & & $\sqrt{ }$ & & & & & & & \\
\hline Legal and contracting knowledge & & & & $\sqrt{ }$ & & & & & & \\
\hline Stakeholder management skills & & & & & $\sqrt{ }$ & $\sqrt{ }$ & & & & \\
\hline
\end{tabular}

Notes: A = Mistarih et al. (2012); B = Quium (2011); C = Canadian Council for PPP (2001); D = Mizrachi and Attar (2011); E = El-Gohary, Osman and El-Diraby (2006); F = Mathur, Price and Austin (2008); G = Turner (2004); H = Akintoye et al. (2003); J = Brown and Potoski (2003); K = PFI Report (2002)

\section{RESEARCH METHODS}

A questionnaire survey was undertaken in Malaysia from October 2013 to March 2014 to determine the SPV organisation skills that enable the effective delivery of PPP projects in Malaysia. In this study, the target survey respondents included industrial practitioners from the public and private institutions, financiers, contractors and other stakeholders that have been involved in the execution of PPP projects.

Survey questionnaires were sent to 95 target respondents who were identified based on purposive sampling technique, where the respondents were considered based on their direct involvement in PPP projects in the study area. In all, 48 completed questionnaires were returned of the 95 distributed; indicating $51 \%$ return rate, which is considered high compared with the norm of $20 \%-30 \%$ for most questionnaire surveys in the construction industry (Akintoye, 2000). 
The respondents' profile in Table 3 shows that 30 respondents, indicating $62.5 \%$ are from public sector organisations and 18 are from the private sector, indicating $37.5 \%$. The composition indicates that both the public and the private sectors were adequately incorporated into the study.

Table 3. Respondents Profile

\begin{tabular}{|c|c|c|}
\hline \multicolumn{3}{|c|}{ Organisation Types } \\
\hline Sector & Frequency & Percentage \\
\hline Public sector & 30 & 62.5 \\
\hline Private sector & 18 & 37.5 \\
\hline Total & 48 & $100 \%$ \\
\hline \multicolumn{3}{|c|}{ Highest Academic Qualifications } \\
\hline Academic Qualification & Frequency & Percentage \\
\hline Degree & 31 & 64.60 \\
\hline Postgraduate qualification & 17 & 35.40 \\
\hline Total & 48 & $100 \%$ \\
\hline \multicolumn{3}{|c|}{ Years of Related PPP Experience } \\
\hline $\begin{array}{l}\text { Years of Related PPP } \\
\text { Experience }\end{array}$ & Frequency & Percentage \\
\hline Five years and below & 6 & 12.5 \\
\hline $6-10$ years & 33 & 68.75 \\
\hline $11-15$ years & 9 & 18.75 \\
\hline Total & 48 & $100 \%$ \\
\hline \multicolumn{3}{|c|}{ Types of PPP Projects } \\
\hline Types of PPP Projects Involved & Frequency & Percentage \\
\hline Transportation & 3 & 6.25 \\
\hline Housing & 8 & 16.67 \\
\hline Education & 13 & 27.08 \\
\hline Power and energy & 10 & 20.83 \\
\hline $\begin{array}{l}\text { Water, sanitation and other } \\
\text { environment related projects }\end{array}$ & 11 & 22.92 \\
\hline Public utilities & 3 & 6.25 \\
\hline Total & 48 & $100 \%$ \\
\hline
\end{tabular}

The table also indicates the academic qualifications of the respondents; respondents with bachelor degree have the highest percentage of $64.60 \%$, while respondents with a postgraduate qualification constitute $35.40 \%$. Majority $(68.75 \%)$ of the respondents have between 6-10 years related PPP experience, followed by respondents with 11-15 years of experience (18.75\%), and lastly the respondents with $0-5$ years of experience (12.5\%). 
The types of PPP projects previously involved by the respondents was identified, wherein education related PPP projects carried the majority of the share at $27.08 \%$, followed by water, sanitation and other environment related projects at $22.92 \%$, power and energy at $20.83 \%$, housing at $16.67 \%$ and lastly transportation and public utilities at $6.25 \%$ respectively. The public utilities PPP projects, refers specifically to tourism and recreational related projects. The wide variety of PPP projects which the respondents were involved in indicated the vast experience and knowledge of the respondents with respect to the implementation of various types of PPP projects, which should enable them to provide more insightful and valuable information for the study. It is to be noted that through cross-checking, although $12.5 \%$ of the respondents were found to have only $0-5$ years related PPP experience, the number of PPP projects that they have been involved substantiates their reliability as suitable respondents of this survey.

\section{Survey Data Analysis and Results}

The relative importance of the 12 skills identified from the literature review was explored by means of a five-point Likert rating scale, where $5=$ Highly important, 4 = Important, 3 = Moderately important, 2 = Mildly important and 1 = Least important. The data was analysed using the SPSS statistical package. The Cronbach's alpha reliability test was firstly undertaken to determine the reliability of the data obtained: the Cronbach's alpha value was 0.708 suggesting that the data collected to be reliable (Norusis, 1992).

However, before deciding which tests to perform on the data, the normality of the data had to be ascertained, the Kolmogorov-Smirnov statistics returned with a $p$-value of sig $=0.000$ which is statistically significant since it is less than 0.05 , indicating the data to be not normally distributed. A significant value of less than 0.05 indicates non normality (Pallant, 2010). Given the above results from the normality test, the non-parametric tests were then used to analyse the data and draw inferences. To compare the two independent samples (public and private sector respondents) the Mann-Whitney $U$ test was employed; which is the nonparametric equivalent of the t-test for independent samples. The Mann Whitney $U$ test was conducted in order to determine the differences in the perceptions of public and private sector respondents on the level of importance of the identified SPV organisation skills sets for PPP project delivery.

From Table 4, which displays the mean ranking of the SPV organisation skills for the PPP infrastructure projects implementation, it shows that "legal and contracting knowledge" is the PPP skill with the overall highest mean and consequently ranked first. This ranking is a clear attestation to the fact identified by Abdul Aziz (2012) with respect to Malaysian housing PPP projects. He reiterated the importance of legal contracting knowledge to ensure the effective delivery of PPP projects. This is related to the principal role that this skill plays in all the aspects of the project delivery, ranging from the rights and responsibilities of the parties involved, project commencement date and expected duration period, basis for extension of time and claiming for liquidated and ascertained damages, concession agreements and grounds for termination of the contract, among others. "Value for money assessment ability" was rated on average as the second most important skill. VfM plays a fundamental role in PPP, as it is considered as one of the crucial requirements before a project can go ahead to be procured via the 
PPP procurement option (Shaoul, 2002; Ismail and Pendlebury, 2006). VfM is described as the optimum combination of whole-of-life costs and quality (or fitness for purpose) of the goods or service to meet the user's requirement (HM Treasury, 2006). It is noted by Takim et al. (2009) and Ismail, Takim and Nawawi (2011), that despite the widespread adoption PPP for delivering infrastructure projects in Malaysia, the implementation policy and the achievement of the VfM objectives in the procurement approach in Malaysia has been the subject of critiques; as the VfM objectives with regards to the achievement of the end user's expectations in the Malaysian practice of PPP for infrastructure projects are not adequately met, although it is clearly an important skill to be able to assess VfM.

Table 4. Perception of Survey Respondents Concerning the Relative Importance of the SPV Organisation Skills for PPP Infrastructure Projects Implementation

\begin{tabular}{|c|c|c|c|c|c|c|c|}
\hline \multirow{2}{*}{\multicolumn{2}{|c|}{ PPP Skills }} & \multicolumn{2}{|c|}{ Public Sector } & \multicolumn{2}{|c|}{ Private Sector } & \multicolumn{2}{|c|}{ Overall } \\
\hline & & \multirow{2}{*}{$\begin{array}{c}\text { Mean } \\
4.50\end{array}$} & \multirow{2}{*}{$\begin{array}{c}\text { Ranking } \\
2\end{array}$} & \multirow{2}{*}{$\begin{array}{c}\text { Mean } \\
4.39\end{array}$} & \multirow{2}{*}{$\begin{array}{c}\text { Ranking } \\
1\end{array}$} & \multirow{2}{*}{$\begin{array}{c}\text { Mean } \\
4.46\end{array}$} & \multirow{2}{*}{$\begin{array}{c}\text { Ranking } \\
1\end{array}$} \\
\hline 1. & $\begin{array}{l}\text { Legal and contracting } \\
\text { knowledge }\end{array}$ & & & & & & \\
\hline 2. & $\begin{array}{l}\text { Value for money } \\
\text { assessment ability }\end{array}$ & 4.47 & 3 & 4.39 & 1 & 4.44 & 2 \\
\hline 3. & $\begin{array}{l}\text { Ability to clearly define } \\
\text { technical and } \\
\text { output/outcome } \\
\text { specifications and } \\
\text { standards for services to } \\
\text { be procured }\end{array}$ & 4.57 & 1 & 4.06 & 6 & 4.38 & 3 \\
\hline 4. & Scoping in/out ability & 4.40 & 4 & 4.06 & 6 & 4.27 & 4 \\
\hline 5. & $\begin{array}{l}\text { Experience in } \\
\text { negotiation and } \\
\text { arbitration }\end{array}$ & 4.20 & 5 & 3.83 & 9 & 4.23 & 5 \\
\hline 6. & $\begin{array}{l}\text { Project management } \\
\text { skills }\end{array}$ & 4.20 & 5 & 4.22 & 3 & 4.21 & 6 \\
\hline 7. & $\begin{array}{l}\text { Communication } \\
\text { capabilities }\end{array}$ & 4.20 & 5 & 4.11 & 5 & 4.17 & 7 \\
\hline 8. & Coordination skills & 4.13 & 6 & 4.17 & 4 & 4.15 & 8 \\
\hline 9. & $\begin{array}{l}\text { Ability to formulate } \\
\text { appropriate performance } \\
\text { measures and } \\
\text { development of } \\
\text { monitoring systems to } \\
\text { determine performance }\end{array}$ & 4.20 & 5 & 3.89 & 8 & 4.08 & 9 \\
\hline 10. & $\begin{array}{l}\text { Technical and } \\
\text { operational innovation } \\
\text { skills }\end{array}$ & 4.13 & 6 & 3.94 & 7 & 4.06 & 10 \\
\hline 11. & $\begin{array}{l}\text { Stakeholder } \\
\text { management skills }\end{array}$ & 4.00 & 8 & 4.06 & 6 & 4.02 & 11 \\
\hline 12. & Conceptual skills & 4.03 & 7 & 3.83 & 9 & 3.96 & 12 \\
\hline
\end{tabular}


"Ability to clearly define technical and output/outcome specifications and standards for services to be procured" occupies the third position. According to Robinson and Scott (2009), a well-drafted output specification is fundamental towards ensuring the successful delivery of PPP projects, as it is the level of services described in the output specification by the public authority and subsequently the performance system measuring the compliance of the PPP concessionaire through the SPV that determines the payment due from the project end users; and moreover serves as reference in the case of any dispute that arises during the PPP project execution and operation.

"Scoping in/out ability" skill was rated as the fourth most important skill, whilst "experience in negotiation and arbitration", "project management skills", "communication capabilities", "coordination skills", "ability to formulate appropriate performance measures and development of monitoring systems to determine performance", "technical and operational innovation skills", "stakeholder management skills" and "conceptual skills" were ranked in relative descending order from the fifth to the 12th based on the mean rating scores of the public and private PPP stakeholder respondents.

In terms of the differences on the perceived mean importance of each skill by the public and private sectors, Table 3 indicates that, "value for money assessment ability" and "legal and contracting knowledge" are considered the most important skills for the private sector, this finding is a clear attestation to the all-encompassing consideration that the private sector has with respect to ensuring that the PPP project delivers the required Valve for money objective. Whilst the ability of the SPV organisation to possess the requisite legal and contracting knowledge required to effectively negotiate the terms and conditions that governs the PPP project is recognised as also being highly important. With respect to the public sector perspective, "ability to clearly define technical and output/outcome specifications and standards for services to be procured" is considered the most important skill that is required by the SPV for the delivery of PPP projects. This finding is a clear attestation to the Malaysian PPP guideline with respect to payment for services offered by the PPP projects: wherein the guideline states that payment for services procured by the PPP is to be based on the predetermined standards and performance as agreed in the contract agreement by the parties of the PPP project (UKAS, 2009). Thereby, this finding is an indication of the underlying desire of the public sector to ensure that the PPP project strictly complies with the agreed specifications and requirements as stipulated in the PPP contract.

Investigating the significant differences in the perceptions of the public and private sectors regarding the relative importance of the twelve SPV organisational PPP skills, the Mann-Whitney $U$ test was employed. The test results as described in Table 5 returned a significant value of 0.024 (less than 0.05 ) for the skill "ability to clearly define technical and output/outcome specifications and standards for services to be procured", whilst the rest were not significant. This clearly points to the conclusion that the private sector does not seem to be matching the priority of the public sector client in prioritising its "ability to clearly define technical and output/outcome specifications and standards for services to be procured". This finding is in tandem with the study undertaken by Ismail, Takim and Nawawi (2011), wherein they identified that the Malaysian public sector procuring party in PPP appears to be more aware on the comprehensive specification of the proposed 
PPP projects compared to contractors, which are responsible to deliver the project. Furthermore, the study has shown that these SPV organisation PPP skills can be categorised into smaller groups (skill sets) considering their relationship to the execution and operation of the PPP project and for this purpose, factor analysis was conducted.

Table 5. Perception of Public and Private Sector Respondents Concerning the Relative Importance of the SPV Organisation Skills for PPP Infrastructure Projects Implementation

\begin{tabular}{|c|c|c|c|c|c|c|}
\hline \multirow[b]{2}{*}{ PPP Skills } & \multicolumn{2}{|c|}{ Median } & \multicolumn{2}{|c|}{ Sample Size } & \multirow[b]{2}{*}{ U } & \multirow{2}{*}{$\begin{array}{c}\text { Significance } \\
\text { Level }\end{array}$} \\
\hline & $\begin{array}{l}\text { Public } \\
\text { Sector }\end{array}$ & $\begin{array}{l}\text { Private } \\
\text { Sector }\end{array}$ & $\begin{array}{l}\text { Public } \\
\text { Sector }\end{array}$ & $\begin{array}{l}\text { Private } \\
\text { Sector }\end{array}$ & & \\
\hline $\begin{array}{l}\text { Legal and } \\
\text { contracting } \\
\text { knowledge }\end{array}$ & 5.00 & 4.00 & 30 & 18 & 240.50 & 0.479 \\
\hline $\begin{array}{l}\text { Value for money } \\
\text { assessment ability }\end{array}$ & 4.50 & 4.00 & 30 & 18 & 245.00 & 0.550 \\
\hline $\begin{array}{l}\text { Ability to clearly } \\
\text { define technical } \\
\text { and } \\
\text { output/outcome } \\
\text { specifications and } \\
\text { standards for } \\
\text { services to be } \\
\text { procured }\end{array}$ & 5.00 & 4.00 & 30 & 18 & 174.00 & $0.024^{*}$ \\
\hline Scoping in/out ability & 4.00 & 4.00 & 30 & 18 & 219.00 & 0.237 \\
\hline $\begin{array}{l}\text { Experience in } \\
\text { negotiation and } \\
\text { arbitration }\end{array}$ & 4.00 & 4.00 & 30 & 18 & 258.50 & 0.786 \\
\hline $\begin{array}{l}\text { Project } \\
\text { management skills }\end{array}$ & 4.00 & 4.00 & 30 & 18 & 261.00 & 0.831 \\
\hline $\begin{array}{l}\text { Communication } \\
\text { capabilities }\end{array}$ & 4.00 & 4.00 & 30 & 18 & 246.00 & 0.565 \\
\hline Coordination skills & 4.00 & 4.00 & 30 & 18 & 260.50 & 0.826 \\
\hline $\begin{array}{l}\text { Ability to formulate } \\
\text { appropriate } \\
\text { performance } \\
\text { measures and } \\
\text { development of } \\
\text { monitoring systems } \\
\text { to determine } \\
\text { performance }\end{array}$ & 4.00 & 4.00 & 30 & 18 & 213.00 & 0.164 \\
\hline $\begin{array}{l}\text { Technical and } \\
\text { operational } \\
\text { innovation skills }\end{array}$ & 4.00 & 4.00 & 30 & 18 & 232.50 & 0.392 \\
\hline $\begin{array}{l}\text { Stakeholder } \\
\text { management skills }\end{array}$ & 4.00 & 4.00 & 30 & 18 & 259.00 & 0.797 \\
\hline Conceptual skills & 4.00 & 4.00 & 30 & 18 & 248.00 & 0.587 \\
\hline
\end{tabular}




\section{Factor Analysis for Skill Sets for the SPV Organisation in PPP Infrastructure Projects}

The purpose of undertaking factor analysis of the various skills is to establish the correlation among these observable skills. This then helps to reduce the number of variables and create a hierarchy of understanding skills at micro and macro levels. The 12 items of the SPV organisational skill for successful PPP infrastructure project delivery were subjected to principal components analysis (PCA) using SPSS version 18. Prior to performing PCA, the suitability of the data for factor analysis was assessed. The Kaiser Meyer-Olkin value was 0.623 , which is satisfactory for factor analysis (Norusis, 1992) and Bartlett's Test of Sphericity has a significant value (p) of 0.000 , thereby meeting the requirement of $(p<0.05)$ supporting the factorability of the correlation matrix (Bartlett, 1954).

Table 6. Factor Loading of SPV Organisational Skills for Successful Delivery of PPP Infrastructure Projects

\begin{tabular}{|c|c|c|c|c|c|}
\hline \multirow{2}{*}{ Factor Components } & \multicolumn{5}{|c|}{ Components } \\
\hline & Factor 1 & Factor 2 & Factor 3 & Factor 4 & Factor 5 \\
\hline $\begin{array}{l}\text { Ability to clearly define } \\
\text { technical output/outcome } \\
\text { specifications and standard } \\
\text { for services to be procured }\end{array}$ & 0.856 & & & & \\
\hline Scoping in/out ability & 0.843 & & & & \\
\hline $\begin{array}{l}\text { Technical and operational } \\
\text { innovation skills }\end{array}$ & 0.582 & & & & \\
\hline $\begin{array}{l}\text { Legal and contracting } \\
\text { knowledge }\end{array}$ & & 0.826 & & & \\
\hline $\begin{array}{l}\text { Experience in negotiation } \\
\text { and arbitration }\end{array}$ & & 0.799 & & & \\
\hline $\begin{array}{l}\text { Value for money } \\
\text { assessment ability }\end{array}$ & & 0.629 & & & \\
\hline Coordination skills & & & 0.825 & & \\
\hline $\begin{array}{l}\text { Communication } \\
\text { capabilities }\end{array}$ & & & 0.671 & & \\
\hline Project management skills & & & 0.566 & & \\
\hline $\begin{array}{l}\text { Ability to formulate } \\
\text { appropriate performance } \\
\text { measures and } \\
\text { development of monitoring } \\
\text { systems to determine } \\
\text { performance }\end{array}$ & & & & 0.875 & \\
\hline Conceptual skills & & & & 0.657 & \\
\hline $\begin{array}{l}\text { Stakeholder management } \\
\text { skills }\end{array}$ & & & & & 0.699 \\
\hline
\end{tabular}

158/PENERBIT UNIVERSITI SAINS MALAYSIA 
Principal components analysis revealed the presence of five components with Eigen values exceeding 1 (see Table 6). Each variable belongs to only one of the factors, with the loading on each factor exceeding 0.50 . The factor analysis showed that the 12 skills are being grouped into five principal factors (skill sets), which are the latent variables and are labeled as follows:

1. Factor grouping 1 represents technical related project skills.

2. Factor grouping 2 represents legal and value related project skills.

3. Factor grouping 3 represents contract administration related project skills.

4. Factor grouping 4 represents conceptual and performance management related project skills.

5. Factor grouping 5 represents stakeholder management related project skills.

\section{Factor Grouping 1: Technical Related Project Skills}

The skill components of project technical related skills are:

1. Ability to clearly define technical output/outcome specifications and standard for services to be procured.

2. Scoping in/out ability.

3. Technical and operational innovation skills.

Technical skills in the SPV organisation in PPP involves the evaluation of designs and the planned facilities in a life cycle scenario including environmental impacts and safety and health considerations with respect to the PPP infrastructure project (Zhang, 2005). When considering PPP procurement options, it is important to review the associated technical related problems. In particular, the contractor needs to ensure that any engineering uncertainties are resolved, in order not to undermine the overall project feasibility (Li et al., 2005). In the project technical related skills, "ability to clearly define technical output /outcome specifications and standard for services to be procured" and "scoping in/out ability" have a high loading (Table 6: significance 0.856 and 0.843 respectively), while "technical and operational innovation skills" has the lowest loading of 0.582.

\section{Factor Grouping 2: Legal and Value Related Project Skills}

The skill sets components of project legal and value related skills are:

1. Legal and contracting knowledge.

2. Experience in negotiation and arbitration.

3. Value for money assessment ability.

An effective understanding and expertise of the legal related aspects of a PPP project by the SPV organisation enables the procurement approach to be implemented without undue legal restriction on the private sector involvement (Li et al., 2005). Having effective legal competencies in PPP projects is imperative as the PPP contracts are supposed to cover every possible aspect of the relationship, including the rights and responsibilities of parties, commencement date and 
duration period, schedule for disbursing the public agencies' entitlements, basis for extension of time, grounds for termination, among other matters (Abdul Aziz, 2012).

In the PPP form of delivering infrastructure, $\mathrm{VfM}$ is considered a pivotal requirement in adopting the innovative partnership collaboration to deliver the needed infrastructure (Shaoul, 2002; Ismail and Pendlebury, 2006). PPP initiatives are about public and private sectors collaborative initiatives that encourage commercial investment in the provision of desired infrastructure facilities and services, by which this is achieved by the apportionment of risks between the parties considered in better position to manage them with the sole aim of achieving VfM (Rosenau, 2000).

In the project legal and value related skills, "legal and contracting knowledge" and "experience in negotiation and arbitration" have a high loading (significance 0.826 and 0.799 respectively), while "value for money assessment ability" has the lowest loading of 0.629 . The legal and value related project skills category is evidently showing a very high correlation of the skills within the category, as well as consisting of the two most important skills identified by both the public and private sector respondents.

\section{Factor Grouping 3: Contract Administration Related Project Skills}

This factor grouping accounts for $10.4 \%$ of the total variances between the skills. The skill components of project contract administration related skills are:

1. Coordination skills.

2. Communication capabilities.

3. Project management skills.

The contract administration skills focuses on the management of roles and responsibilities of parties to the PPP contract by the SPV organisation during the PPP project conception, execution and subsequent operation stages by which is required to effectively deliver the intended objectives of the PPP project (Devkar and Kalidindi, 2013). In the project contract administration related skills, "coordination skills" has the highest loading of 0.825 , while "communication capabilities" has a loading of 0.671 , while "project management skills" has the lowest loading of 0.566 .

\section{Factor Grouping 4: Conceptual and Performance Monitoring Project Skills}

This factor grouping accounts for $9.7 \%$ of the total variances between skill sets. The skill sets components of project conceptual and performance monitoring skills are:

1. Ability to formulate appropriate performance measures and development of monitoring systems to determine performance.

2. Conceptual skills.

Performance measurement is the process of quantifying the efficiency and effectiveness of action of organisations based on their initial set out objectives (Neely, 1999). According to Cates et al. (2002), in the private sector led SPV just like any strategically intent organisation, effective performance management skills will 
enable the SPV to achieve the following objectives towards delivering enhanced infrastructure project and services, these objectives includes:

1. impact on organisation reputation,

2. improved measured of organisational knowledge and lastly

3. increased ability to provide customer value.

Another skill that forms part of this categorisation is that of "conceptual skills". For the innovative procurement approach in PPP to achieve its desired objectives, there is the need for the continued development and incorporation of organisational concepts and mechanisms that hold promise for (1) mobilising resources beyond those available to public sector entities alone and (2) offering solutions to complex problems; In particular, these concepts are developed in terms of policy development, infrastructure and service delivery, capacity building and lastly economic development. With these concepts, the PPP approach is expected to be analytically valid and practically worthwhile in delivering its promises and expectations (Brinkerhoff and Brinkerhoff, 2011).

In the project conceptual and performance monitoring skills, "ability to formulate appropriate performance measures and development of monitoring systems to determine performance" have a high loading, while "conceptual skills" have a lower loading (significance 0.875 and 0.657 respectively).

\section{Factor Grouping 5: Stakeholder Management Related Project Skills}

This factor accounts for $8.8 \%$ of the total variability between critical success factors. There is only one skill component under this factor grouping, which is "stakeholder management skills" (significance 0.699). In relation to infrastructure projects development, a stakeholder refers to any person or organisation that has a legitimate interest in a project (Bourne, 2005). In the context of infrastructure development "stakeholder involvement" has now replaced the more limited term of "public involvement"; as such in the PPP infrastructure project, the public needs to be effectively involved in order to ensure that the underlying objectives of the procurement approach is being achieved. However, the public has to be taken in full confidence that their involvement will influence the decision making process (El-Gohary, Osman and El-Diraby, 2006).

\section{IMPLICATIONS, LIMITATIONS AND CONCLUSION}

This paper has established the relative importance of skills in SPV organisations with respect to the delivery of PPP projects. Based on the descriptive quantitative data provided by public and private sector stakeholders involved in PPP projects in Malaysia, "legal and contracting knowledge" and "conceptual skills" were respectively identified as the most and least important of the SPV organisation skills for PPP project delivery. Furthermore, "ability to clearly define technical and output/outcome specifications and standards for services to be procured" differed significantly in terms of level of importance between the public sector and private sector respondents. This significant mismatch implies that the issue of skills alignment needs serious attention. 
There are limitations with respect to this study. The limitations relates to the difficulty of achieving high response rate. This is contributed by the fact of a limited number of people with sufficient experience in PPP projects in Malaysia. In order to substantiate this piece of work, it is highly recommended that triangulation using the qualitative approach be also undertaken undertaken in order to increase the reliability of the findings of this research in view of having to settle for low response rate. Additionally, further evidence based research needs to be undertaken in order to establish the relationships of the various hypothesis that are implied here.

It is suggested in this paper that the slow progression of the SPV organisation to deliver enhanced PPP project objectives can be attributed to the prolonged transition phase of the current institutionalised form of construction project skills acquisition that has yet to place greater emphasis on SPV organisation PPP skill sets such as "risk management", "negotiation", "strategic financing capabilities", etc. as key components of the SPV.

The findings of this research study is expected to contribute to the body of knowledge with respect to the critical role that the skills of the private sector led SPV organisation plays in delivering projects through the innovative approach in PPP. This serves to highlight the importance of aligning the roles and responsibilities of the various stakeholders with the relevant skills. Additionally this study provides all key stakeholders under the SPV organisation the opportunity to align their resources within the respective skill sets (factor groupings) at the higher conceptual level and then address the specific skills to be procured at the micro level for the improved delivery of the infrastructure needs of society through the PPP approach.

\section{REFERENCES}

Abdul Aziz, A.R. (2012). Control mechanisms exercised in Malaysian housing public private partnerships. Construction Management and Economics, 30(1): 3755. doi: 10.1080/01446193.2011.654129.

Abdul Rashid, K. (2007). Private Finance Initiative (PFI): Concept and Method of Procurement for Construction Projects with Specific Reference to Malaysia. Kuala Lumpur: International Islamic University Malaysia.

Abdullah, N., Sufian, A., Asenova, D. and Bailey, S.J. (2012). PPP/PFI in Malaysian development plans: Purpose, structure, implementation, financing and risk transfer. Journal of Risk and Governance, 3(2): 69.

Akintoye, A. (2000). Analysis of factors influencing project cost estimating practice. Construction Management and Economics, 18(1): 77-89. doi: 10.1080/014461900370979.

Akintoye, A., Edwards, P.J. and Hardcastle, C. (2005). The allocation of risk in PPP/PFI construction projects in the UK. International Journal of Project Management, 23(1): 25-35. doi: 10.1016/j.ijproman.2004.04.006.

Akintoye, A., Hardcastle, C., Beck, M., Chinyio, E. and Asenova, D. (2003). Achieving best value in private finance initiative project procurement. Construction Management and Economics, 21(5): 461-470. doi: $10.1080 / 0144619032000087285$.

Asian Development Bank (ADB). (2008). Public-Private Partnership Handbook. September. Manila: ADB.

162/PENERBIT UNIVERSITI SAINS MALAYSIA 
Bartlett, M.S. (1954). A note on the multiplying factors for various chi square approximations. Journal of the Royal Statistical Society, 16(Series B): 296-298.

Booth, K. and Skilling, H. (2007). Structuring a PPP: Selecting the Option. Manila: ADB. Available at: http://www.adb.org/sites/default/files/institutionaldocument/31484/public-private-partnership.pdf [Accessed on 12 August 2013].

Bourne, L. (2005). Project relationship management and the stakeholder circle. PhD diss. RMIT University.

Brinkerhoff, D.W. and Brinkerhoff, J.M. (2011). Public-private partnerships: Perspectives on purposes, publicness and good governance. Public Administration and Development, 31 (1): 2-14. doi: 10.1002/pad.584.

Brown, T. and Potoski, M. (2003). Managing contract performance: A transaction cost approach. Journal of Policy Analysis and Management, 22(2): 275-297. doi: $10.1177 / 1530957603026004003$.

Canadian Council for PPP. (2001). 100 Projects: Selected Public-Private Partnerships. Ottawa: Canadian Council for PPP.

Cates, T., Overby, J., Robbins, S.P. and Coulter, M. (2002). Management: Test Item File 2. Upper Saddle River, NJ: Prentice Hall.

Chowdhury, A.B.U., Orr, R.J. and Settel, D. (2009). Multilaterals and infrastructure funds: A new era. Journal of Structured Finance, 14(4): 68-74. doi: 10.3905/JSF.2009.14.4.068.

Chowdhury, A.N., Chen, P.H. and Tiong, R.L. (2011). Analysing the structure of public-private partnership projects using network theory. Construction Management and Economics, 29(3): 247-260. doi: 10.1080/01446193.2010.537354.

Devkar, G.A. and Kalidindi, S.N. (2013). External agencies for supplementing competencies in Indian urban PPP projects. Built Environment Project and Asset Management, 3(1): 58-73. doi: 10.1 108/BEPAM-05-2012-0023.

Economic Planning Unit (EPU). (2006). Ninth Malaysia Plan (2006-2010). Putrajaya: EPU. Available at: http://www.epu.jpm.my/rm9/html/english.htm [Accessed on 12 April 2012].

El-Gohary, N.M., Osman, H. and El-Diraby, T.E. (2006). Stakeholder management for public private partnerships. International Journal of Project Management, 24(7): 595-604. doi: 10.1016/j.ijproman.2006.07.009.

Gomez, C.P. and Gambo, M.M. (2013). Structuring best value delivery process of PPP infrastructure projects in Malaysia. The Construction, Building and Real Estate Research Conference of the Royal Institute of Chartered Surveyors. New Delhi: Royal Institute of Chartered Surveyors.

Gunawasa, A. (2012). Public private partnerships for major infrastructure projects in developing countries. In G. Ofori (ed.). Contemporary Issues in Construction in Developing Countries. London: Spon Press.

Harris, S. (2003). Public Private Partnerships: Delivering Better Infrastructure Services. Washington DC: Inter-American Development Bank. Available at: http://www.alide.org/DataBank2007/RecInformation/2APP_Infraestructure/4 1 PublicPPharrisBID.pdf [Accessed on 10 March 2013].

HM Treasury. (2006). Valve for Money Assessment Guidance. London: HM Treasury.

Huang, T., Shen, L.Y., Yam, C.H. and Zhao, Z.Y. (2005). An analysis to the existing practice of managing government-invested project in China. Construction Economics: 16-20. 
Ismail, K., Takim, R. and Nawawi, A.H. (2011). The evaluation criteria of value for money (VfM) of public private partnership (PPP) bids. International Conference on Intelligent Building and Management. Singapore: IACSIT Press, 349-355.

Ismail, S. and Pendlebury, M. (2006). The private finance initiative (PFI) in schools: The experiences. Financial Accountability and Management, 22(4): 381404. doi: $10.1111 /$ j.1468-0408.2006.00431.x.

Koch, C. and Buser, M. (2006). Emerging metagovernance as an institutional framework for public private partnership networks in Denmark. International Journal of Project Management, 24(7): 548-556. doi:10.1016/j.jproman.2006. 07.001 .

Li, B., Akintoye, A., Edwards, P.J. and Hardcastle, C. (2005). Critical success factors for PPP/PFI projects in the UK construction industry. Construction Management and Economics, 23(5): 459-471. doi:10.1080/014461905 00041537.

Mathur, V.N., Price, A.D. and Austin, S. (2008). Conceptualizing stakeholder engagement in the context of sustainability and its assessment. Construction Management and Economics, 26(6): 601-609. doi: 10.1080/01446190802061233.

Mistarih, A., Al Refai, M., Al Qaid, B. and Qeed, M. (2012). Competency requirements for managing public private partnerships. International Journal of Business Management, 7(12): 60-73.

Mizrachi, Y. and Ben-Attar, D. (2011). "Downtown" and "suburbia" public-private partnerships (PPP) in the application of information and communication technologies for development (ICT4D). In H.S. Desivilya (ed.). The Paradox in Partnership: The Role of Conflict in Partnership Building. Sharjah, UAE: Bentham Science Publishers Ltd.

Neely, A. (1999). The performance measurement revolution: Why now and what next? International Journal of Operations and Production Management, 19(2): 205-228. doi: 10.1 108/01443579910247437.

Norusis, M.J. (1992). SPSS for Windows: Base System User's Guide. New York: SPSS Incorporated.

Pallant, J. (2010). SPSS Survival Manual: A Step by Step Guide to Data Analysis Using SPSS. Berkshire, UK: McGraw-Hill International.

Peterson, T.O. and Van Fleet, D.D. (2004). The ongoing legacy of RL Katz: An updated typology of management skills. Management Decision, 42(10): 1297-1308. doi: 10.1108/00251740410568980.

PFI Report. (2002). Super Contractors for Super Hospitals. London: National Audit Office.

Quium, A. (2011). A Guidebook on Public-Private Partnership in Infrastructure. Bangkok: United Nations Economic and Social Commission for Asia and the Pacific (UNESCAP).

Robinson, H.S. and Scott, J. (2009). Service delivery and performance monitoring in PFI/PPP projects. Construction Management and Economics, 27(2):181-197. doi: 10.1080/01446190802614163.

Rosenau, P.V. (ed.). (2000). Public-Private Policy Partnerships. Cambridge, US: MIT Press.

Royal Institution of Chartered Surveyors (RICS) Project Management Forum. (2003). PFI and the Skills of a Manager. London: RICS. 
Salleh, D. and Siong, H.C. (2008). The involvement of private sector in local infrastructure development in Malaysia. Jurnal Alam Bina, 11 (2): 74-100.

Shaoul, J. (2002). New developments: A financial appraisal of the London underground public-private partnership. Public Money and Management 22(2): 53-60. doi: $10.1111 / 1467-9302.00308$.

Takim, R., Ismail, K., Nawawi, A.H. and Jaafar, A. (2009). The Malaysian private finance initiative and value for money. Asian Social Science, 5(3): 103-111. doi: $10.5539 /$ ass.v5n3p103.

Turner, J.R. (2004). Farsighted project contract management: Incomplete in its entirety. Construction Management and Economics, 22(1): 75-83. doi: 10.1080/0144619042000186077.

Unit Kerjasama Awam Swasta (UKAS). (2009). Garis Panduan Kerjasama Awam Swasta (Guideline on PPP). Putrajaya, Malaysia: UKAS. Available at: http://www.ukas.gov.my/c/document_library/get_file? uuid=02flea81-80754387-8b69-ebb21 20292f1 \&groupld=15223 [Accessed on 15 September 2012].

Walker, C.T. (1995). Privatized Infrastructure: The Build Operate Transfer Approach. London: Thomas Telford. doi: 10.1680/pitba.20535.

Whetten, D. (2005). Developing Managerial Skills. Chennai, India: Pearson Education India.

Woodhouse, E. (2006). IPP study case selection and project outcomes: An additional note. Working Paper: Program on Energy and Sustainable Development at the Center for Environmental Science and Policy. Stanford, CA: Stanford University. Available at: http://pesd.fsi.stanford.edu/sites/ default/files/IPP_Study___Country_and_Project_Annex.pdf [Accessed on 20 November 2014].

Zhang, X. (2005). Critical success factors for public-private partnerships in infrastructure development. Journal of Construction Engineering and Management, 131 (1): 3-14. doi: 10.1061/(ASCE)0733-9364(2005)131:1 (3). 